\title{
Synthesis of azaheterocycles by one electron reduction of oximes ${ }^{1}$
}

\author{
Koichi Narasaka* and Mitsuru Kitamura \\ Department of Chemistry, Graduate School of Science, The University of Tokyo \\ 7-3-1 Hongo, Bunkyo-ku, Tokyo 113-0033, Japan \\ E-mail: narasaka@chem.s.u-tokyo.ac.jp
}

\begin{abstract}
Anion radicals generated by one-electron reduction of oxime derivatives act as iminyl radical equivalents. That is, the intramolecular $\mathrm{C}-\mathrm{N}$ bond formation of $\gamma, \delta$-unsaturated or $\beta$-aryl oximes is induced by one electron reduction to give various pyrroles, quinolines, and carbolines. The catalytic electron transfer processes are developed by using hydroquinones or copper reagents as electron donors. Photo-induced electron transfer is also applied to the transformation of $\gamma, \delta$ unsaturated oximes to dihydropyrroles.
\end{abstract}

Keywords: Oxime, radical cyclization, iminyl radical, anion radical

\section{Contents}

1. Cyclization of phenethyl ketone $\mathrm{O}$-2,4-dinitrophenyloximes with $\mathrm{NaH}$

2. Cyclization of $O$-acetyloximes of $\gamma, \delta$-unsaturated ketones by photochemical electron transfer

3. Hydroquinone-catalyzed cyclization of $O$-acetyloximes of $\gamma, \delta$-unsaturated ketones

4. Cyclization of $O$-acyloximes of $\gamma, \delta$-unsaturated or $\beta$-indolyl ketones with copper-catalysts

\section{Introduction}

Various reactions of oximes have been developed, among them, Beckmann rearrangement is most frequently employed in organic synthesis. ${ }^{2}$ In this rearrangement, C-N bond is newly formed with the migration of anti substituent and the resulting $N$-substituted nitrilium ion intermediates have been widely exploited as synthetic intermediates not only for amide formation but also for preparation of azaheterocycles. We found that $\mathrm{S}_{\mathrm{N}} 2$-type substitution reaction proceeded at the oxime $\mathrm{sp}^{2}$ nitrogen. For example, anti $O$-sulfonyloximes having an 
active methine group are cyclized by treatment with a base such as DBU, whereas the corresponding syn isomers are not (Scheme 1$).^{3}$

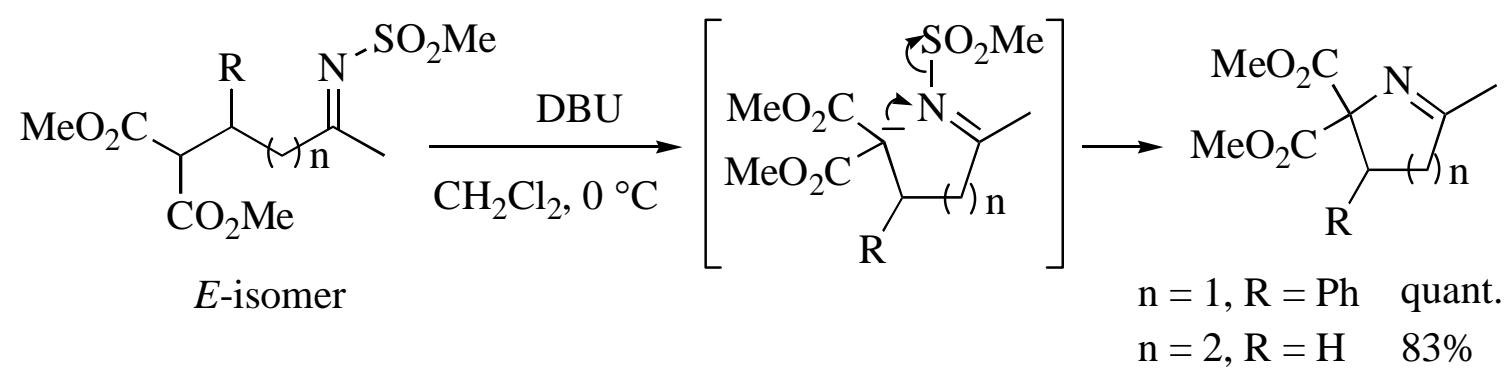

\section{Scheme 1}

During the course of the study on this abnormal $\mathrm{S}_{\mathrm{N}} 2$-type reaction at $\mathrm{sp}^{2}$ atoms, we observed that anion radicals of oxime derivatives acted as alkylideneaminyl radical equivalents (vide infra), and were utilized as reactive intermediates for $\mathrm{C}-\mathrm{N}$ bond formation. In this review are described some synthetic reactions via the anion radicals of oximes that are mainly developed in our laboratory. ${ }^{3}$

\section{Cyclization of $O$-2,4-Dinitrophenyloximes of Phenethyl or $\gamma, \delta$ - Unsaturated Ketones}

As it was supposed that the combination of nucleophiles and leaving groups should be important to promote the $\mathrm{S}_{\mathrm{N}}$ 2-type substitution at the oxime nitrogen, the cyclization of 2-(3hydroxyphenyl)ethyl ketone oximes was examined by introducing some leaving groups on the oxime nitrogen.

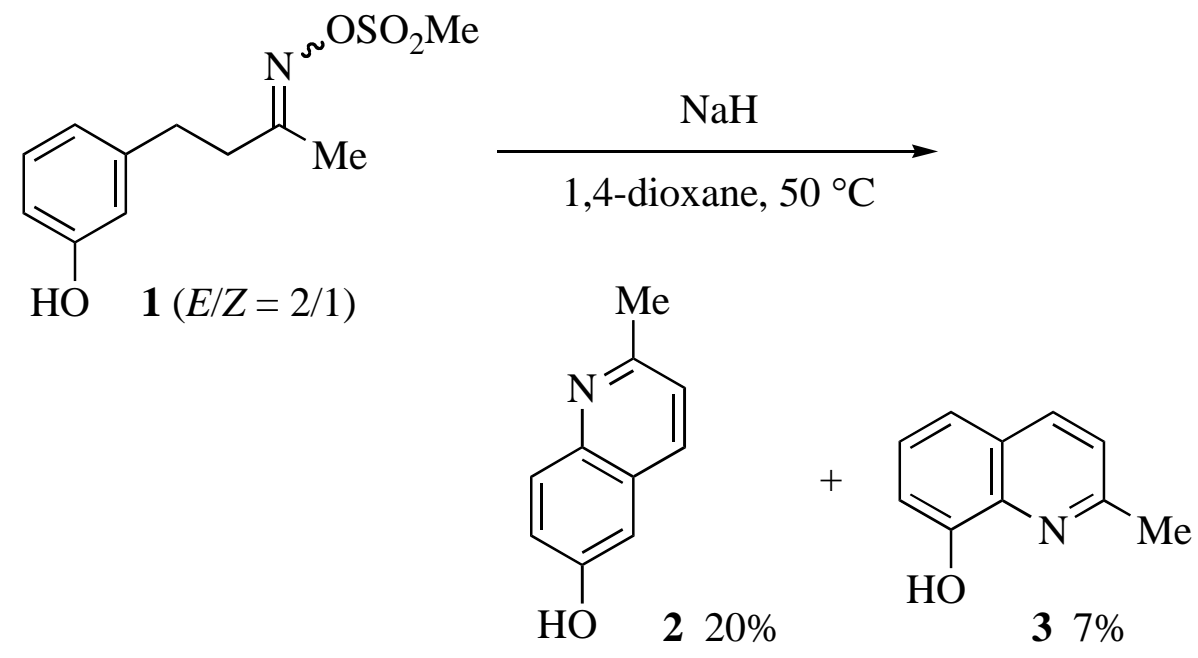

\section{Scheme 2}


When a mixture of $(E)$ and $(Z)-O$-methylsulfonyloximes 1 was treated with excess amounts of NaH, 6- and 8-quinolinols (2 and 3) were obtained in a low total yield (Scheme 2). ${ }^{4}$ In contrast, the similar reaction of $O$-2,4-dinitrophenyloxime $\mathbf{4}$ yielded 8-quinolinol 3 and its tetrahydro derivative 6 in high yield without forming 6-quinolinol (Scheme 3). ${ }^{5}$ More interestingly, either $E$ - and Z-isomers $\mathbf{4}$ smoothly cyclized to give 8-quinolinols $\mathbf{3}$ and $\mathbf{6}$.

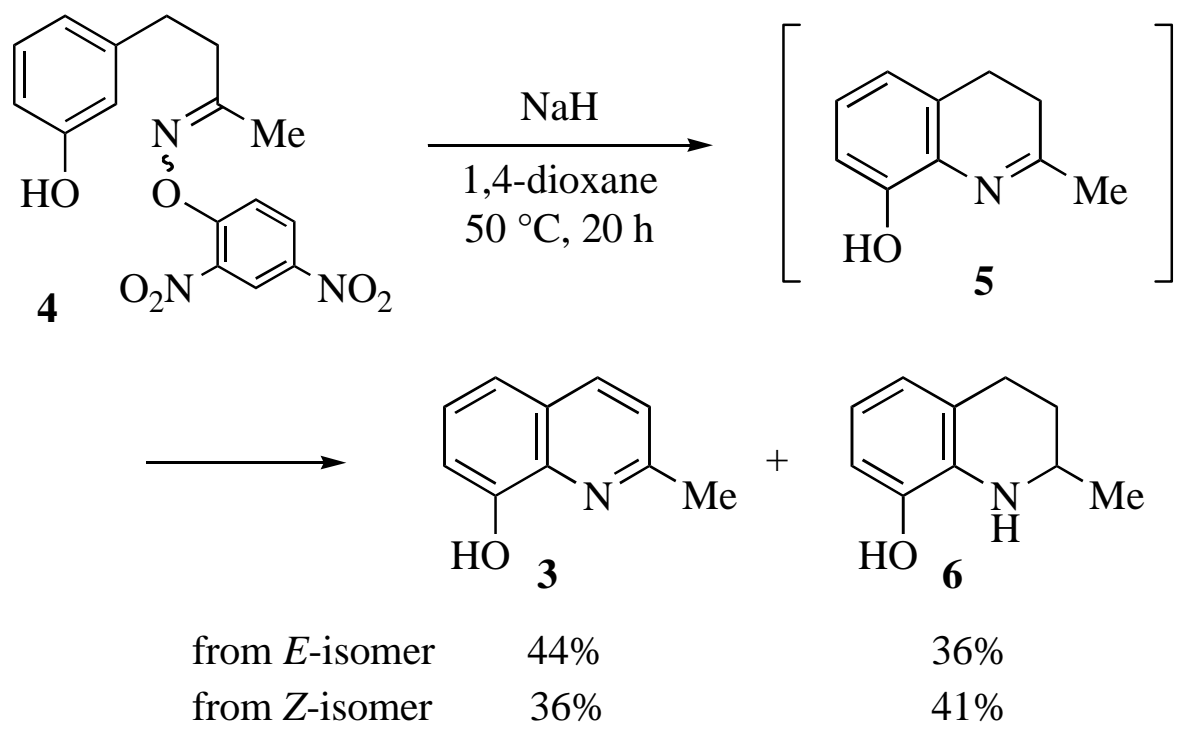

\section{Scheme 3}

The smooth cyclization of both $(E)$ and $(Z)-O-2,4$-dinitrophenyl derivatives was not explained by $\mathrm{S}_{\mathrm{N}}$ 2-type reaction, because the $E$, Z-isomerization hardly occurred under the reaction conditions.<smiles>C/C(CCc1cccc(O)c1)=N/Oc1cccc([N+](=O)[O-])c1</smiles>

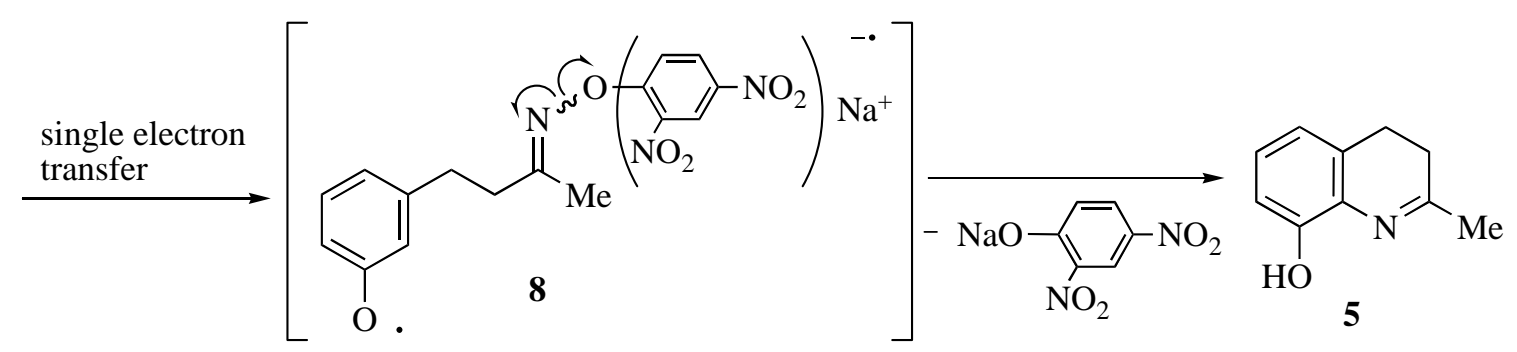

Scheme 4 
Finally, it was found that the complex of phenoxide and excess $\mathrm{NaH}$ worked as a good electron donor, and quinolines $\mathbf{3}$ and $\mathbf{6}$ were formed by radical process induced by intramolecular electron transfer from the phenoxide-excess $\mathrm{NaH}$ complex to dinitrophenyl group in 7 (Scheme 4). In the resulting anion radical species $\mathbf{8}$, radical coupling between phenoxyl radical and oxime nitrogen proceeds with the elimination of 2,4-dinitrophenoxide.

By this transformation, two products such as quinolinols and the tetrahydro derivatives were always produced as the result of the disproportionation of the preliminary formed dihydroquinolinol 5. 8-Quinolinols 10 were found to be exclusively prepared from 2-(3hydroxyphenyl)ethyl ketone $O$-2,4-dinitrophenyloximes 9 by the radical cyclization and the successive one-pot oxidation with 2,3-dichloro-5,6-dicyano-p-benzoquinone (DDQ) and acetic acid (Scheme 5). ${ }^{4}$ In contrast, when the cyclization was carried out with $\mathrm{NaH}$ in the presence of a reducing reagent, $\mathrm{NaBH}_{3} \mathrm{CN}$, instead of quinolinols, tertrahydro-8-quinolinols 12 were obtained (Scheme 6). ${ }^{6}$ Both methods exhibited wide generality and various 8-quinolinols and tetrahydro-8-quinolinols were synthesized selectively from $\beta$-(3-hydroxyphenyl) oximes. In addition, it was quite noteworthy that both stereoisomers of $O$-2,4-dinitrophenyloximes can be employed in the synthesis of quinolinol derivatives in all cases.<smiles>CC1(C)OC/C(=N\Oc2ccc([N+](=O)[O-])cc2[N+](=O)[O-])C(Cc2cccc(O)c2)O1</smiles>

9
1) $\mathrm{NaH}$

1,4-dioxane, $50{ }^{\circ} \mathrm{C}$

2) $\mathrm{DDQ}, \mathrm{AcOH}$<smiles>CC1(C)OCC2=Nc3c(O)cccc3CC2O1</smiles><smiles>CC1(C)OCc2nc3c(O)cccc3cc2O1</smiles>

$1060 \%$

\section{Scheme 5}

Thus $m$-hydroxyphenethyl ketone oximes may be transformed to 8-quinolinol derivatives by intramolecular electron transfer. In azaheterocycle synthesis, iminyl radicals have been employed as one of the reactive intermediates, ${ }^{7}$ in which oxime derivatives have been used as the radical sources. For example, Forrester et al. reported the synthesis of quinolines by the cyclization of iminyl radical formed by the oxidation of $O$-hydroxycarbonylmethyloxime (Scheme 7). ${ }^{8}$ Zard et al. have studied extensively the generation of iminyl radical species from oximes and their addition reaction to internal alkenes. ${ }^{9,10}$ Various methods have been developed for the generation of iminyl radical species; such as the action of $n \mathrm{Bu}_{3} \mathrm{SnH} / \mathrm{AIBN}$ on $O$ - 
substituted oxime (Scheme 8), the reduction of $O$-acetyloxime with nickel powder, and so on. Weinreb recently devised an efficient cyclization method of O-2,6dimethylbenzenesulfinyloximes by applying the Hudson reaction (Scheme 9). ${ }^{11}$

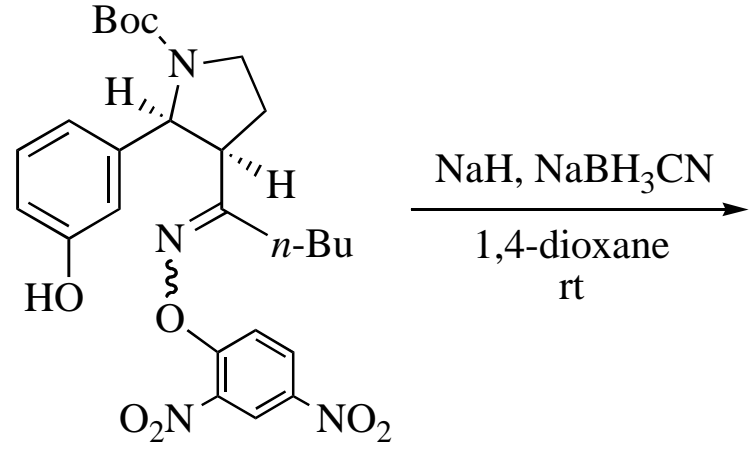

11<smiles>O=C(OCc1ccccc1)N1CC[C@@H]2C(Br)=Nc3c(O)cccc3[C@H]21</smiles><smiles>CC(C)(C)OC(=O)[C@@H]1Nc2c(O)cccc2[C@@H]2[C@@H]1CCN2C(=O)OC(C)(C)C</smiles>

\section{Scheme 6}

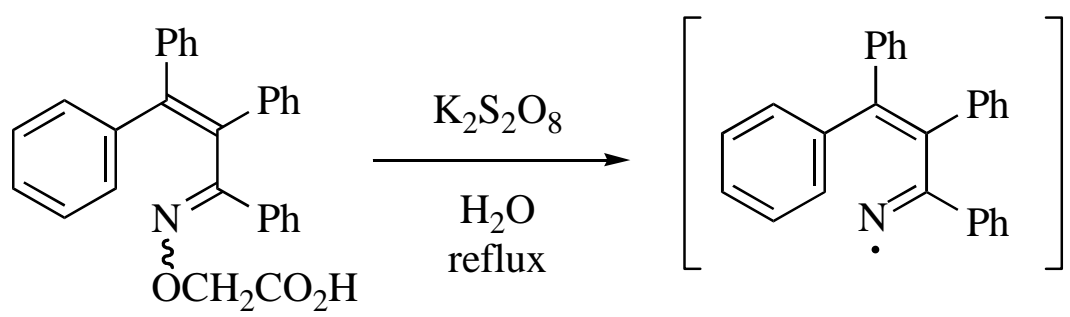<smiles>c1ccc(-c2nc3ccccc3c(-c3ccccc3)c2-c2ccccc2)cc1</smiles>

Scheme 7<smiles>C=CCC1CCCCC1=NOCC(=O)c1ccccc1</smiles>

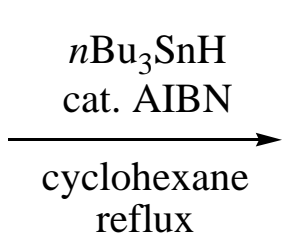<smiles>C=CCC1CCCCC1=NC</smiles><smiles>CC1CC2CCCCC2=N1</smiles>

\section{Scheme 8}




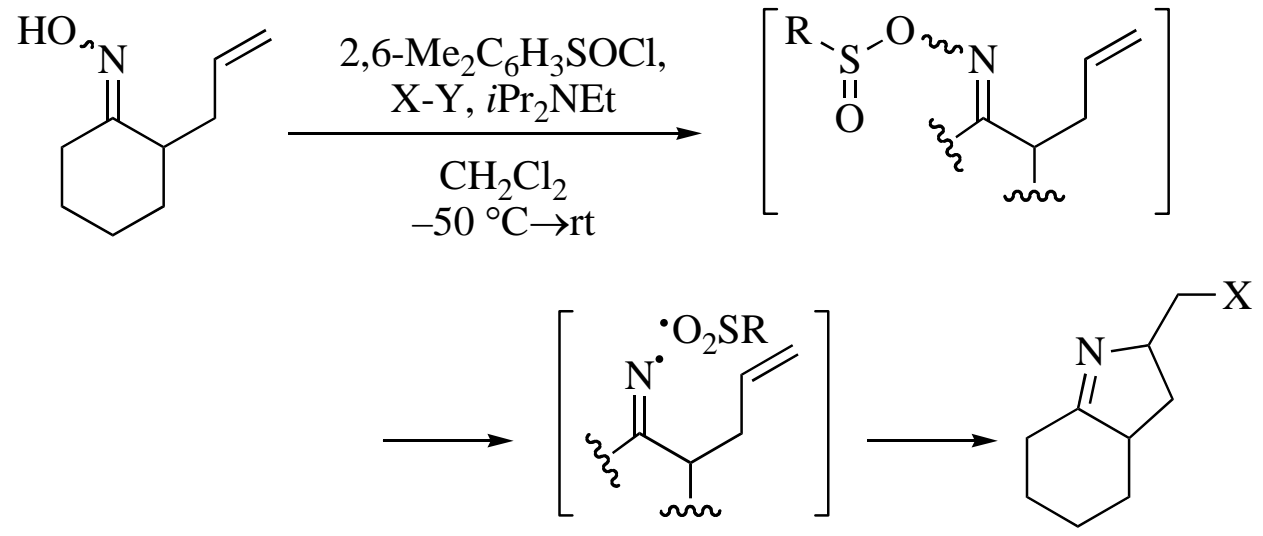

$\mathrm{X}-\mathrm{Y}=(\mathrm{PhSe})_{2},(\mathrm{PhS})_{2}, \mathrm{TEMPO}, 1,4$-cyclohexadiene

\section{Scheme 9}

Quinoline formation from 2,4-dinitrophenyl oximes prompted us to study the radical cyclization of $\gamma, \delta$-unsaturated $O$-2,4-dinitrophenyloximes. In this case, the addition of an electron donor is required, and the combination of 3,4-methylenedioxyphenol (sesamol) and excess amounts of $\mathrm{NaH}$ worked efficiently for the cyclization. The treatment of cis-2-allyl-4phenylcyclohexanone (E)-O-2,4-dinitrophenyloxime (13) with $\mathrm{NaH}$, sesamol, and 1,4cyclohexadiene (CHD) in 1,4-dioxane at $50{ }^{\circ} \mathrm{C}$ afforded cyclic imine $\mathbf{1 4}$ in $91 \%$ yield (Scheme 10). ${ }^{12}$ Some other radical trapping reagents such as $\mathrm{CCl}_{4},(\mathrm{PhS})_{2}$, and $(\mathrm{PhSe})_{2}$ were also utilized as radical terminators.
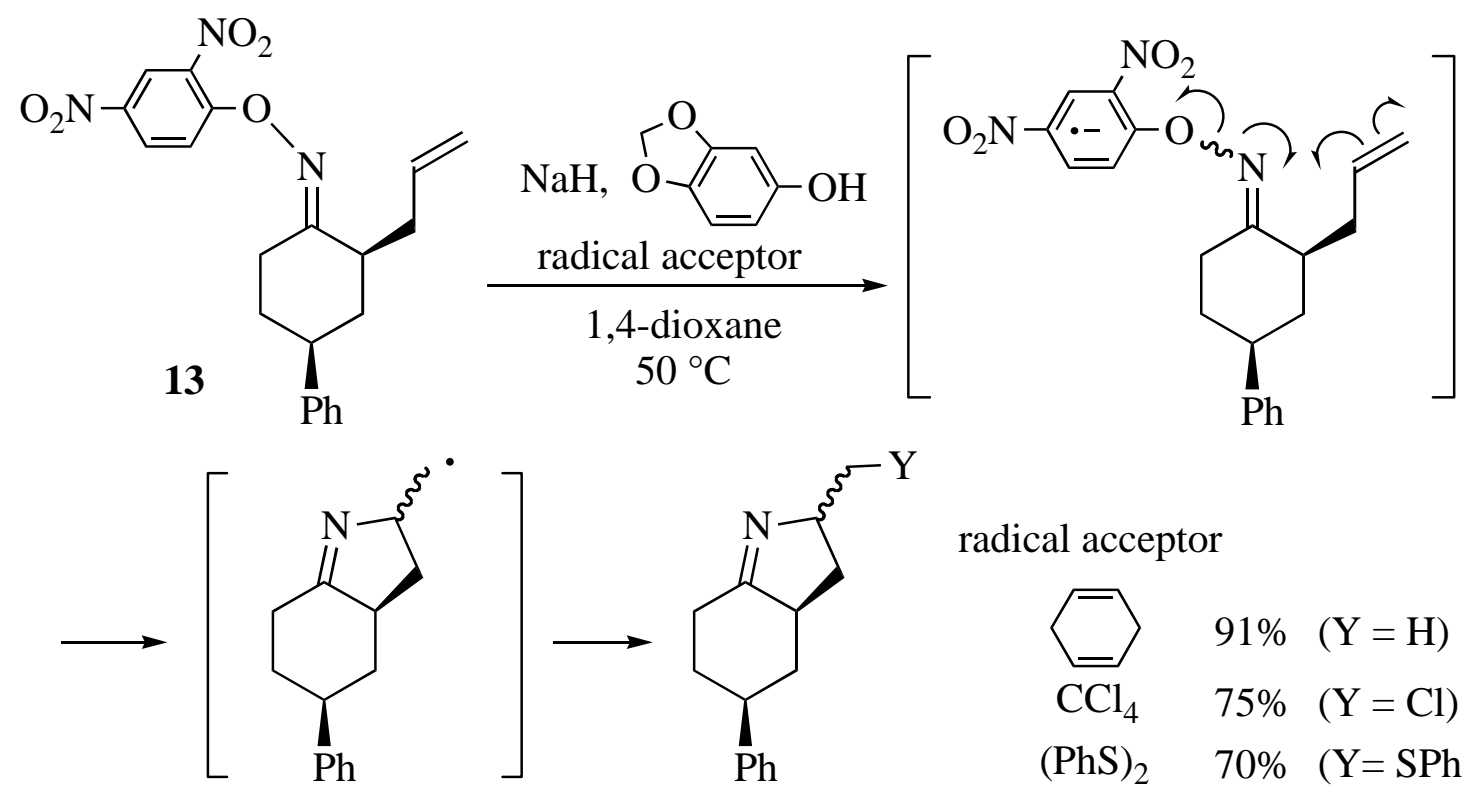

radical acceptor

14

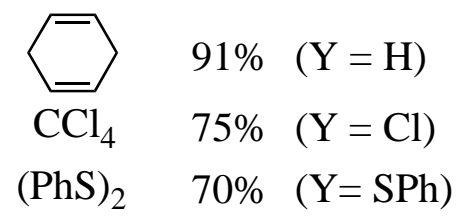

$(\mathrm{PhSe})_{2} \quad 69 \% \quad(\mathrm{Y}=\mathrm{SePh})$

Scheme 10 


\section{Cyclization of $O$-Acetyloximes of $\gamma, \delta$-Unsaturated Ketones by Photochemical Electron Transfer}

Although it becomes apparent that one electron reduction of $O$-2,4-dinitrophenyloximes induces the radical cyclization to afford azaheterocycles, the reaction has to be performed under strongly basic conditions, and 2,4-dinitrophenyl group is not a good leaving group in atom economy. Accordingly, we next tried to modify this radical reaction to catalytic processes.

Photo irradiation $(\lambda>320 \mathrm{~nm})$ of a mixture of $\gamma, \delta$-unsaturated $O$-( $p$-cyanophenyl)oxime 15 and 1,5-dimethoxynaphthalene (DMN) in acetonitrile gave 3,4-dihydro-2H-pyrrole 18 (Scheme 11). ${ }^{13}$ The reaction is initiated by one-electron transfer from the exited DMN to 15 , and the thus formed anion radical $\mathbf{1 6}$ cyclizes to generate alkyl radical intermediate $\mathbf{1 7}$ with the elimination of p-cyanophenoxide. Then alkyl radical 17 is trapped with 1,4-cyclohexadiene to yield cyclic imine 18. To make the electron transfer efficient, a $p$-cyanophenyl group was introduced as a substituent of the oxime oxygen, but it was not easy to prepare the $O$-p-cyanophenyoximes. It was desired to replace $p$-cyanophenyl group with simple substituent that was more readily available as a starting material.<smiles>[R]C(CCC=C)=NOc1ccc(C#N)cc1</smiles>

$15 \mathrm{R}=\mathrm{Ph}\left(\mathrm{CH}_{2}\right)_{2}$

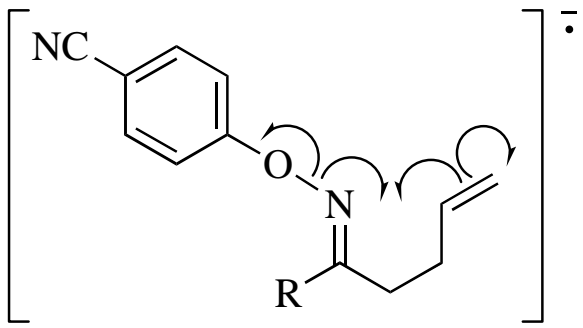

16

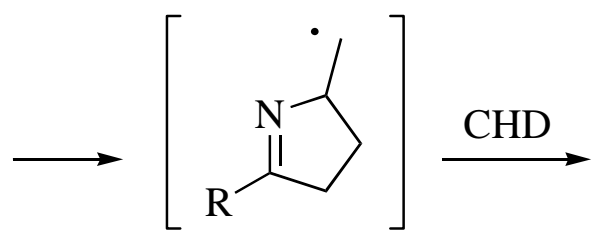

17

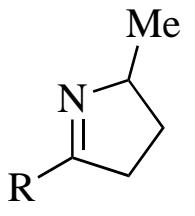

$1875 \%$

$\mathrm{DMN}=1,5$-dimethoxynaphthalene, $\mathrm{CHD}=1,4$-cyclohexadiene

\section{Scheme 11}

Of course, $\gamma, \delta$-unsaturated $O$-acetyloxime 19a was hardly cyclized by photo-induced electron transfer with DMN (yield of 20a and 21a is 4\%), because the $O$-acetyloxime did not act as a good electron acceptor. The addition of acetic acid, however, accelerated the electron transfer, in which the protonated $O$-acetyloxime, generated in equilibrium, might work as a good electron acceptor. That is, in the presence of 10 molar amounts of acetic acid, $\gamma, \delta$-unsaturated ketone $O$-acetyloxime 19a cyclized to 4-acetoxymethy-3,4-dihydropyrroles 20a and 21a in 
acetonitrile under photo irradiation $(\lambda>300 \mathrm{~nm})$ in the presence of 1,5-dimethoxynaphthalene $(\mathrm{DMN})$ as a catalytic sensitizer (Scheme 12). ${ }^{14}$ The addition of a small amount of 1,4cyclohexadiene (20 mol\%) made the reaction cleaner. It presumably acted as a scavenger of some radical species such as those generated from the solvent.

This cyclization is induced by single electron transfer (SET) from excited DMN to protonated oxime 19a and the cyclization with the cleavage of the $\mathrm{N}-\mathrm{O}$ bond gives alkyl radical species 22 (Scheme 12). Back electron transfer (BET) from 22 to the cation radical of DMN regenerates the sensitizer, DMN, and cationic species like 23 is trapped with AcOH immediately to give acetoxymethyl $2 \mathrm{H}$-dihydrpyrrole 20a. Methylated dihydropyrrole 21a is formed from alkyl radical species 22 by abstracting hydrogen from 1,4-cyclohexadiene (CHD).

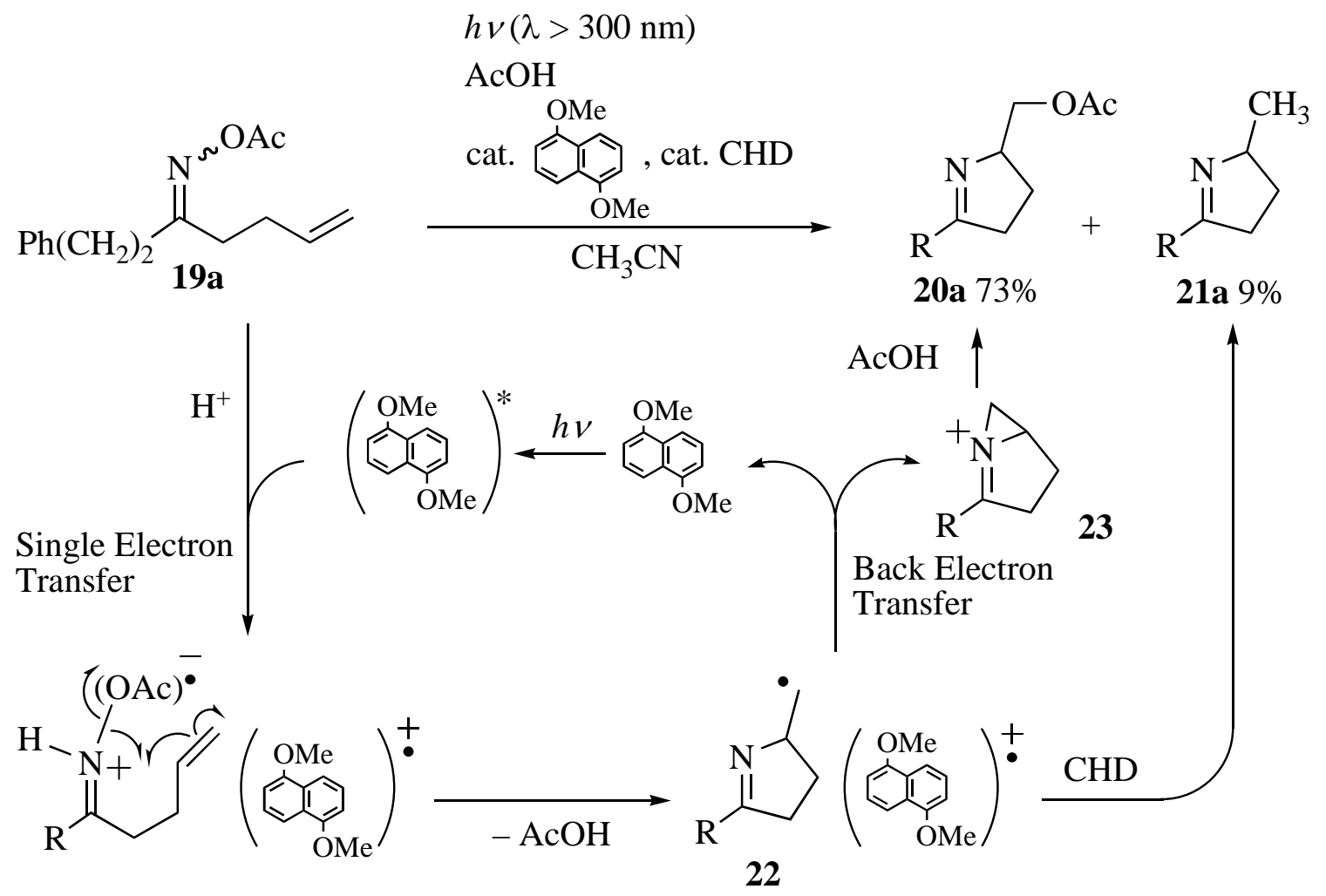

\section{Scheme 12}

Various $\gamma, \delta$-unsaturated $O$-acetyloximes of alkyl ketones were converted to dihydropyrroles (Table 1). Cyclization of 19 having a terminal vinyl group gave acetoxymethyl cyclic imine 20 and a small amount of hydrogenated one 21 (run 1), while oximes having an internal alkenyl moiety gave acetoxymethyl imines 20 exclusively (runs 2-4). From $\gamma$-substituted $\gamma, \delta$-unsaturated oxime 19, pyridine 24 was formed in 15\% yield via 6-endo cyclization along with a 58\% total yield of 5-membered cyclic imines (run 5). 
<smiles>[R]C([R])=C([R])CCC(CCc1ccccc1)=NOC(C)=O</smiles><smiles></smiles>

Table 1. Photochemical cyclization of $O$-acetyloximes 19

\begin{tabular}{llllll}
\hline Run & $\mathrm{R}^{1}$ & $\mathrm{R}^{2}$ & $\mathrm{R}^{3}$ & $\mathbf{2 0} / \%$ & $\mathbf{2 1} / \%$ \\
\hline 1 & $\mathrm{H}$ & $\mathrm{H}$ & $\mathrm{H}$ & 73 & 9 \\
2 & $\mathrm{H}$ & $\mathrm{Me}$ & $\mathrm{H}$ & 82 & 0 \\
3 & $\mathrm{H}$ & $\mathrm{Ph}$ & $\mathrm{H}$ & 76 & 0 \\
4 & $\mathrm{Me}$ & $\mathrm{Me}$ & $\mathrm{H}$ & 80 & 0 \\
$5^{\mathrm{a}}$ & $\mathrm{H}$ & $\mathrm{H}$ & $\mathrm{Me}$ & 47 & 11 \\
\hline
\end{tabular}

a) 24 was obtained in 15\% yield<smiles>Cc1ccc(CCc2ccccc2)nc1</smiles>

Thus the cyclization of alkyl ketone $O$-acetyloximes 19 proceeded by photo-sensitized electron transfer in the presence of acetic acid, whereas acetic acid did not show any effect in the cyclization of aryl or conjugated ketone oximes 25. The cyclization of $\mathbf{2 5}$ finished within a shorter time as compared that of non-conjugated oximes 19, and 2-methyldihydropyrroles 26 were obtained instead of 2-acetoxymethyl derivatives (Scheme 13). Because the cyclization proceeded quite slowly in the absence of DMN, the reaction seemed to be initiated by energy transfer through the exciplex formation between $\mathrm{DMN}^{*}$ and conjugated oximes.

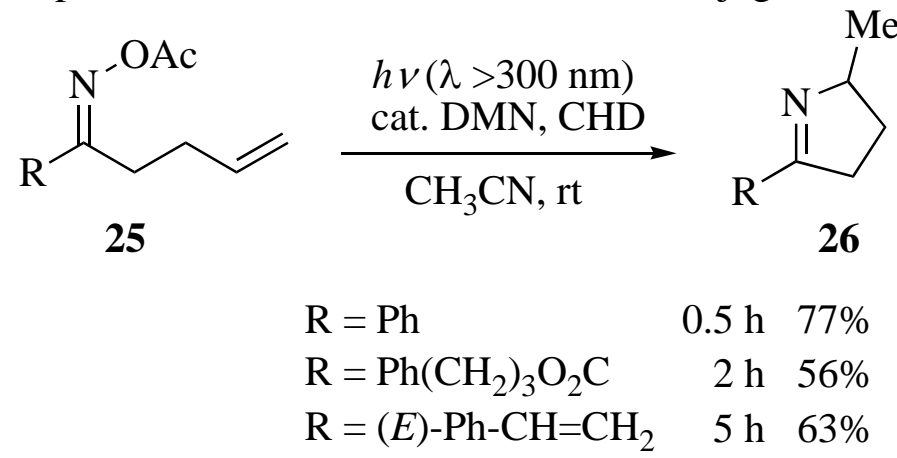

\section{Scheme 13}


Concerning photochemical radical reaction of oximes, Zard et al. reported an efficient radical chain cyclization of $O$-methylthiothiocarbonyloxime initiated by homolytic cleavage of $\mathrm{N}-\mathrm{O}$ bond by photo irradiation (Scheme 14$).^{10 \mathrm{c}}$

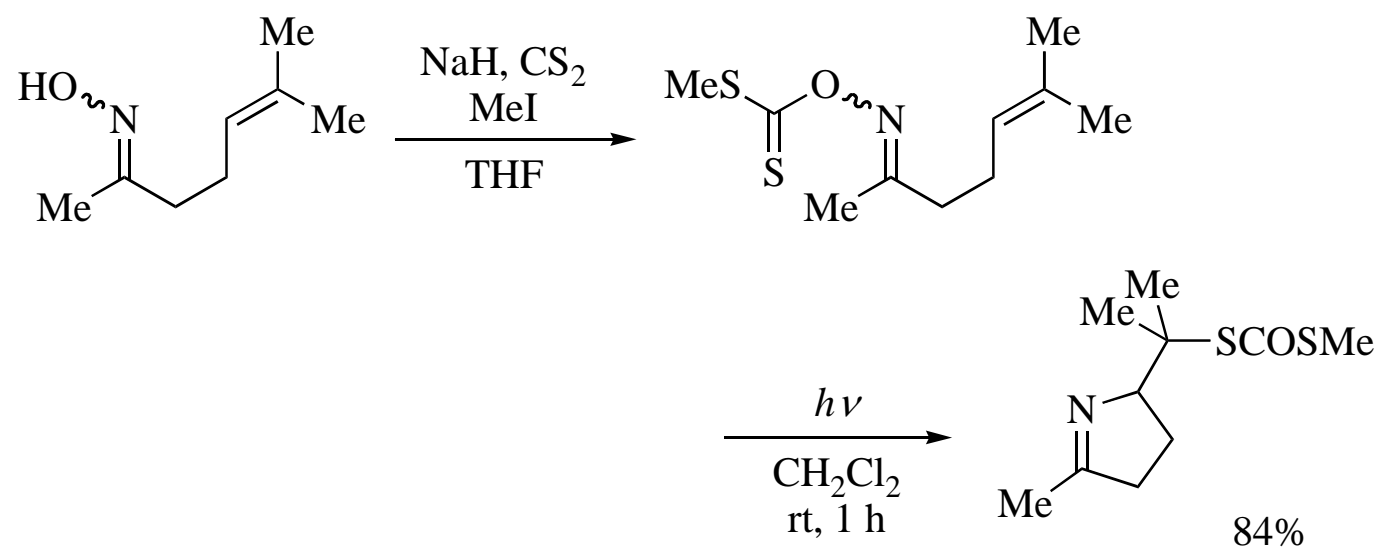

Scheme 14

\section{Hydroquinone-catalyzed Cyclization of $O$-Acetyloximes of $\gamma, \delta$-Unsaturated Ketones}

In addition to the photochemical one electron reduction, catalytic radical cyclizations of $\gamma, \delta$-unsaturated $O$-acetyloxime were explored by employing electron donor catalysts. In the first example, dihydroquinone (or 1,5-naphthalenediol) was found to catalyze the cyclization with the coexistence of acetic acid. When a 1,4-dioxane solution of $\gamma, \delta$-unsaturated $O$-acetyloxime 19a, acetic acid, CHD, and a catalytic amount of hydroquinone was heated, methyl-dihydropyrrole 21a was obtained in 53\% yield along with the $\mathrm{S}_{\mathrm{N}} 2$-type substitution product, acetoxymethyl derivative 20a (Scheme 15). ${ }^{15}$

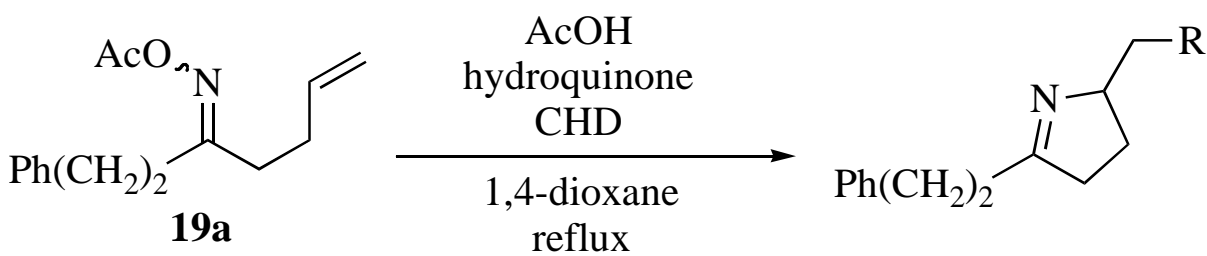

$$
\begin{aligned}
& \text { 20a } R=\text { OAc } \\
& \text { 21a } R=H \quad 53 \%
\end{aligned}
$$

\section{Scheme 15}

As shown in the Scheme 16, one-electron transfer occurs from hydroquinone to the protonated $O$-acetyloxime 19 , and the resulting protonated anion radical 27 cyclizes to generate 
alkyl radical 28, which abstracts hydrogen from 1,4-cyclohexadiene. The catalyst, hydroquinone, is regenerated from phenoxyl radical by hydrogen abstraction from 1,4cyclohexadiene.<smiles>[R]C(=O)ON=C([R])CCC=C</smiles>

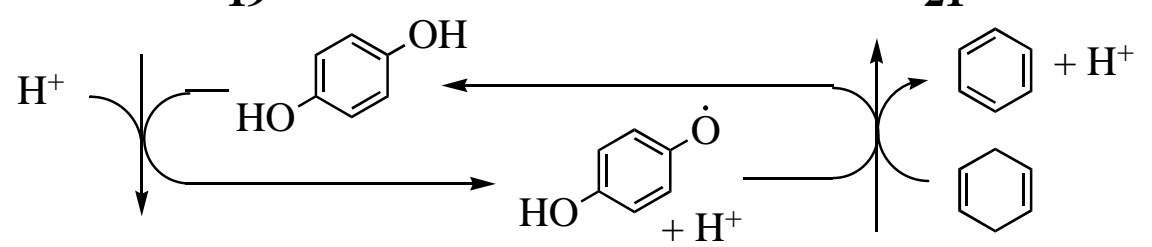<smiles>[R]C1=NC([CH])CC1</smiles>

\section{Scheme 16}

By the reaction of $O$-acetyloxime 19 having an electron-rich olefinic moiety, the olefinic moiety acted as a nuceophile and acetoxymethyl derivative $\mathbf{2 0}$ was obtained as a major product by $\mathrm{S}_{\mathrm{N}} 2$-type cyclization (Table 2, runs 2 and 3). In contrast, only radical cyclization products 21 were obtained from oximes 19 which had electron-deficient olefinic moiety (runs 4 and 5). $O$ Acyloximes of phenyl ketone and $\alpha$-keto ester also cyclized to give only radical cyclization product, dihydropyrroles 21 (run 6 and 7).<smiles>[R]C([R])=CCCC([R])=NOC(C)=O</smiles>

19

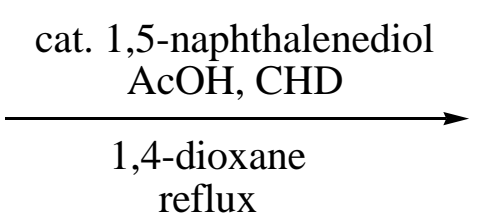<smiles>[R]C1=NC(C([R])([R])[R])CC1</smiles> 
Table 2. Cyclization of $O$-acetyloximes 19 catalyzed by paphthalenediol

\begin{tabular}{llllllll}
\hline run & $\mathrm{R}^{1}$ & $\mathrm{R}^{2}$ & $\mathrm{R}^{3}$ & syn:anti & time & $\mathbf{2 0} / \%$ & $\mathbf{2 1 / \%}$ \\
\hline 1 & $\mathrm{Ph}\left(\mathrm{CH}_{2}\right)_{2}$ & $\mathrm{H}$ & $\mathrm{H}$ & $1: 1$ & $6 \mathrm{~h}$ & 34 & 52 \\
2 & $\mathrm{Ph}\left(\mathrm{CH}_{2}\right)_{2}$ & $\mathrm{Me}$ & $\mathrm{H}$ & $1: 1$ & $6 \mathrm{~h}$ & 67 & 16 \\
3 & $\mathrm{Ph}\left(\mathrm{CH}_{2}\right)_{2}$ & $\mathrm{Me}$ & $\mathrm{Me}$ & $1: 1$ & $6 \mathrm{~h}$ & 72 & 5 \\
4 & $\mathrm{Ph}\left(\mathrm{CH}_{2}\right)_{2}$ & $\mathrm{CN}$ & $\mathrm{H}$ & $1: 1$ & $12 \mathrm{~h}$ & 0 & 69 \\
5 & $\mathrm{Ph}\left(\mathrm{CH}_{2}\right)_{2}$ & $\mathrm{CO}_{2} \mathrm{Et}$ & $\mathrm{H}$ & $1: 2$ & $12 \mathrm{~h}$ & 0 & 72 \\
6 & $\mathrm{Ph}$ & $\mathrm{H}$ & $\mathrm{H}$ & $>99:<1$ & $8 \mathrm{~h}$ & 0 & 75 \\
$7^{\text {a }}$ & $\mathrm{Ph}\left(\mathrm{CH}_{2}\right)_{2} \mathrm{O}_{2} \mathrm{C}$ & $\mathrm{H}$ & $\mathrm{H}$ & $>99:<1$ & $6 \mathrm{~h}$ & 0 & 67 \\
\hline
\end{tabular}

a) $O$-Pivaloyloxime was used instead of $O$-acetyloxime

This method could be applied to the preparation of pyrroles from $\gamma, \delta$-unsaturated $O$ acetyloximes having an alkynyl moiety as shown in Scheme $17 .{ }^{15 b}$ Both alkyl and aryl ketoximes 29 having a terminal alkynyl group were converted to 2,5-disubstituted pyrroles 30 in good yield irrespective of the terminal substituent on the alkynyl group.<smiles>[R]C#CCCC([R])=NOC(C)=O</smiles>

29

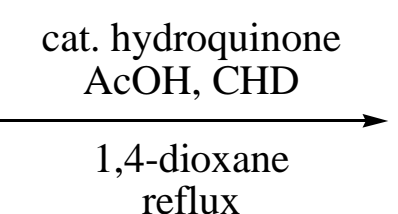

reflux<smiles>[R]Cc1ccc([R])[nH]1</smiles>

30

\begin{tabular}{lll}
$\mathrm{R}^{1}$ & $\mathrm{R}^{2}$ & \\
\hline $\mathrm{Ph}\left(\mathrm{CH}_{2}\right)_{2}$ & $\mathrm{H}$ & $67 \%$ \\
$\mathrm{Ph}$ & $\mathrm{H}$ & $67 \%$ \\
$\mathrm{Ph}$ & $\mathrm{Me}$ & $72 \%$ \\
$\mathrm{Ph}$ & $\mathrm{CO}_{2} \mathrm{Et}$ & $83 \%$
\end{tabular}

\section{Scheme 17}

\section{Cyclization of $O$-Acyloximes of $\gamma, \delta$-Unsaturated or $\beta$-Indolyl Ketones with Copper-Catalysts}

It was expected that oxime derivatives would be reduced with low valent transition metal compounds. Such an example was reported by Zard. That is, the treatment of $\gamma, \delta$-unsaturated $O$ acetyloximes with nickel powder and acetic acid in 2-propanol leads to the cyclization to dihydropyrroles. $^{9 \mathrm{c}}$ The reaction, however, requires large excess amounts of nickel powder, and it is desirable to conduct such a transformation in a catalytic manner. 
Copper(I) was found to work as a redox catalyst. ${ }^{16}$ When a syn/anti $(1: 1)$ mixture ${ }^{2}$ of $O$ methoxycarbonyloxime of $\gamma, \delta$-unsaturated ketone 31a and $5 \mathrm{~mol} \%$ of $\mathrm{CuBr} \cdot \mathrm{SMe}_{2}$ in 1,4-dioxane was heated to $80^{\circ} \mathrm{C}$, cyclic imine 21a was obtained in 39\% yield (Table 3, run 2). The product yield was improved by the addition of $\mathrm{LiBr}$, and 4-bromomethyl-3.4-dihydropyrrole 32a was obtained in $86 \%$ (run 1 ). As well as $O$-methoxycarbonyloxime, $O$-pentafluorobenzoyloxime was cyclized in high yield, whereas the corresponding $O$-2,4-dinitrophenyl and $O$-acetyloximes were not appropriate for this catalytic system. The reaction probably proceeds by electron transfer from copper(I) salt to the oxime 31, generating anion radical, which in turn cyclizes to give 32 with the elimination of $\mathrm{Cu}(\mathrm{I})$ methyl carbonate.
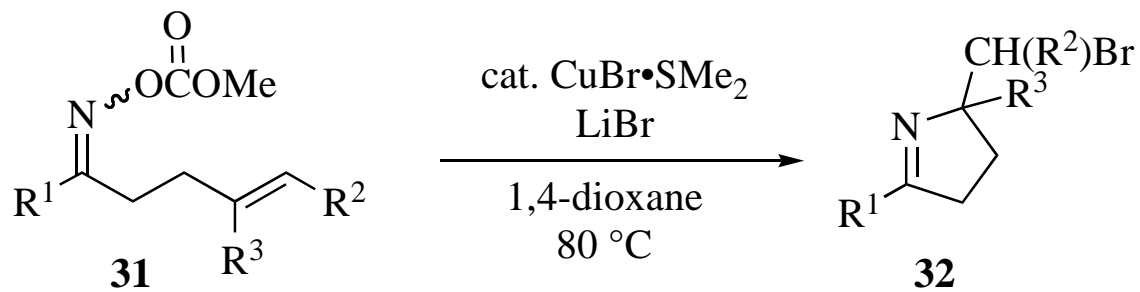

Table 3. Cu-catalyzed cyclization of $O$-methoxycarbonyloximes 31

\begin{tabular}{lllll}
\hline run & $\mathrm{R}^{1}$ & $\mathrm{R}^{2}$ & $\mathrm{R}^{3}$ & Yield/\% \\
\hline 1 & $\mathrm{Ph}\left(\mathrm{CH}_{2}\right)_{2}$ & $\mathrm{H}$ & $\mathrm{H}$ & 86 \\
$2^{\mathrm{a}}$ & $\mathrm{Ph}\left(\mathrm{CH}_{2}\right)_{2}$ & $\mathrm{H}$ & $\mathrm{H}$ & $39(\mathbf{2 1 a})$ \\
3 & $\mathrm{Ph}\left(\mathrm{CH}_{2}\right)_{2}$ & $\mathrm{Me}$ & $\mathrm{H}$ & 85 \\
4 & $\mathrm{Ph}\left(\mathrm{CH}_{2}\right)_{2}$ & $\mathrm{Ph}$ & $\mathrm{H}$ & 74 \\
$5^{\mathrm{b}}$ & $\mathrm{Ph}\left(\mathrm{CH}_{2}\right)_{2}$ & $\mathrm{H}$ & $\mathrm{Me}$ & 53 \\
6 & $\mathrm{Ph}$ & $\mathrm{H}$ & $\mathrm{H}$ & 83 \\
7 & $\mathrm{CO}_{2} \mathrm{Et}$ & $\mathrm{H}$ & $\mathrm{H}$ & 53 \\
\hline
\end{tabular}

a) Without LiBr. b) 24 was obtained in $16 \%$ yield.<smiles>Cc1ccc(CCc2ccccc2)nc1</smiles>

The catalytic process with $\mathrm{CuBr} \bullet \mathrm{SMe}_{2}-\mathrm{LiBr}$ could be applied to the cyclization of various $\gamma, \delta$-unsaturated ketone $O$-methoxycarbonyloximes as shown in Table 3. Cyclization of oximes having $\gamma, \delta$-disubstituted alkenyl moiety gave cyclic imines in high yield (runs 3,4). From $\gamma$ methyl substituted oxime, 5,5-disubstituted dihydropyrrole was obtained in 53\% yield along with 16\% yield of disubstituted pyridine 24 (run 5). Phenyl ketone and $\alpha$-keto ester oximes were smoothly transformed into 2-phenyl and 2-ethoxycarbonyl dihydropyrroles, respectively (runs 6, 7). 
This copper-promoted cyclization of $\gamma, \delta$-unsaturated oximes was applied to the construction of the key framework of peduncularine (33), ${ }^{17}$ 6-azabicyclo[3.2.1]octene. ${ }^{18}$ That is, $O$-pentafluorobenzoyloxime having 7-oxa-bicyclo[2.2.1]octene moiety $\mathbf{3 4}$ was cyclized to the desired tricyclic imine $\mathbf{3 5}$ in good yield as a mixture of the endo and exo bromides by the treatment with either a stoichiometric or a catalytic amount of $\mathrm{CuBr} \bullet \mathrm{SMe}_{2}$. The reductive ring opening of 35 proceeded smoothly with lithium naphthalenide to afford the desired 6azabicyclooctene 36 .

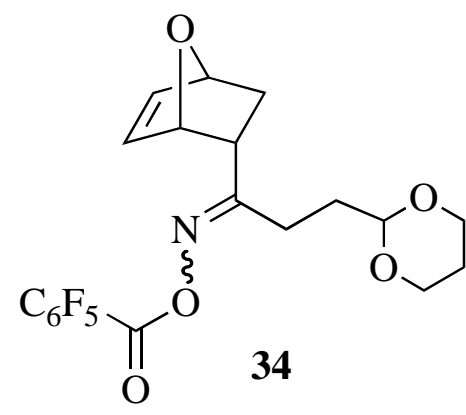

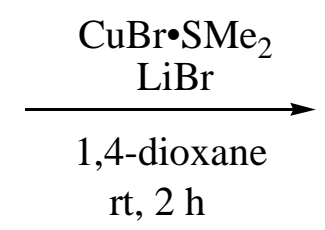

lithium naphthalenide

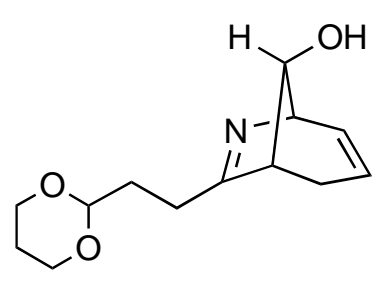

36<smiles>BrC1CC2=NC(CCC3OCCCO3)C3CC1OC23</smiles>

35 Stoichiometric 98\% cat. $\mathrm{CuBr} \cdot \mathrm{SMe}_{2} 75 \%$

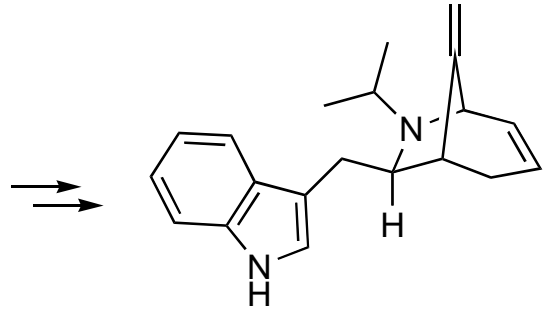

peduncularine (33)

\section{Scheme 18}

Furthermore, $\alpha$-carbolines 38 were prepared by radical cyclization of $\beta$-3-indolyl ketone $O$-pentafluorobenzoyloximes $\mathbf{3 7}$ with a catalytic amount of copper powder in dichloroethane and by the successive oxidation with chloranil (Scheme 19). ${ }^{19}$ In this radical cyclization, copper powder gradually reacted with 1,2-dichloroethane to generate copper(I) salt, which acted as an active redox catalyst for the anion radical generation.

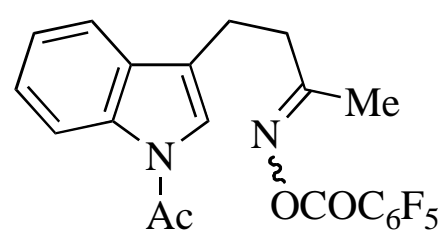

37
1) cat. $\mathrm{Cu}$ powder $\mathrm{MeN}\left(\mathrm{CH}_{2} \mathrm{CH}_{2} \mathrm{NMe}_{2}\right)_{2}$ $\mathrm{ClCH}_{2} \mathrm{CH}_{2} \mathrm{Cl}, 80^{\circ} \mathrm{C}$

2) chloranil, $\mathrm{CH}_{2} \mathrm{Cl}_{2}$, rt<smiles>Cc1ccc2c3ccccc3n(C3CCCCC3)c2n1</smiles>

38 75\%

\section{Scheme 19}


This cyclization made a clear contrast to the $\mathrm{S}_{\mathrm{N}} 2$-type cyclization of the similar $\beta$-indolyl oximes 39, which gave spiro[indoline-3,2'-pyrrolidine] derivatives $\mathbf{4 0}$. Thus, by the choice of the reaction-types, $\alpha$-carbolines $\mathbf{3 8}$ and spiroindolines $\mathbf{4 0}$ can be prepared from $\beta$-indolyl oximes 37 and $39 .^{20}$

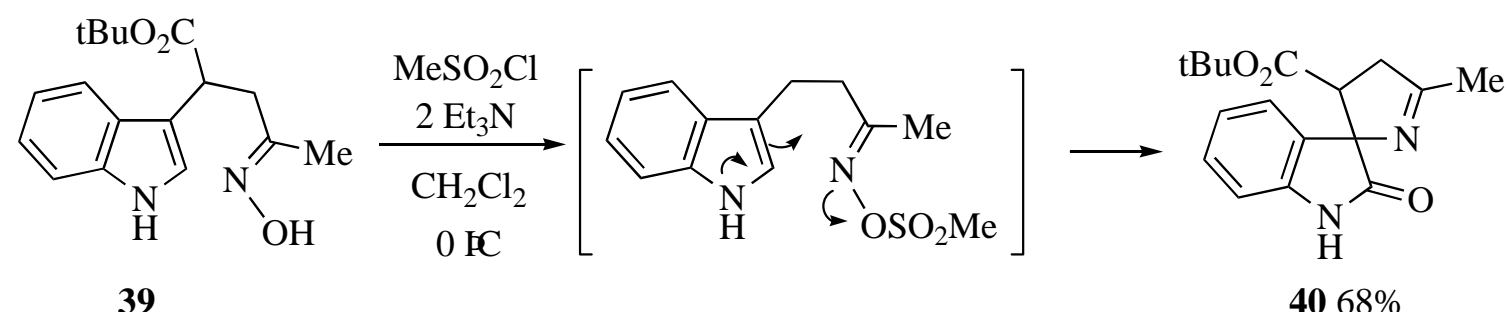

\section{Scheme 20}

\section{References}

1. Recent reviews on oximes. (a) Abele, E.; Lukevics, E. Heterocycles 2000, 53, 2285. (b) Narasaka, K.; Yamane, M. In Science of Synthesis, Vol. 27: Carbons with Two CarbonHeteroatom Bonds: Heteroatom Analogues of Aldehydes and Ketones; Padwa; A. Ed., Thieme: Stuttgart, 2004, Ch.15. (c) Kitamura, M.; Narasaka, K. Synth. Org. Chem. Jpn. 2004, 62, 38.

2. (a) Gawley, R. E. Org. React. 1988, 35, 1. (b) Maruoka, K.; Yamamoto, H. In Comprehensive Organic Synthesis: Functional Group Transformations via Carbonyl Derivatives; Trost, B. M.; Fleming, I., Eds.; Pergamon: Oxford, 1996, Vol. 6, pp 763. (c) Donaruma, L. G.; Heldt, W. Z. Org. React. 1960, 11, 1. (d) Conley, R. T.; Ghosh, S. Mech. Mol. Migr. 1971, 4, 197. (e) Beckwith, A. L. J. In The Chemistry of Amides, Zabicky, J., Ed.; Interscience: New York, 1970, p.131. (f) Smith, P. A. S. In Molecular Rearrangements, Pert I, de Mayo, P. Ed., Interscience: New York, 1962, p.483.

3. Previously, we partially reviewed on this topic. (a) Narasaka, K. Pure. Appl. Chem. 2003, 75, 19. (b) Narasaka, K. Pure. Appl. Chem. 2002, 74, 143.

4. Uchiyama, K; Ono, A.; Hayashi, Y.; Narasaka, K. Bull. Chem. Soc. Jpn. 1998, 71, 2945.

5. Uchiyama, K; Hayashi, Y; Narasaka, K. Synlett 1997, 445.

6. Ono, A; Uchiyama, K.; Hayashi, Y. Narasaka, K. Chem. Lett. 1998, 437.

7. (a) Fallis, A. G.; Brinza, I. M. Tetrahedron 1997, 53, 17543. (b) Mikami, T.; Narasaka, K. In Advances in Free Radical Chemistry; Zard, S. Z., Ed.; JAI: Stamford, 1999; Vol. 2, pp 45. (c) Stella, L. In Radicals in Organic Synthesis; Renaud, P.; Sibi, M. P., Eds.; Wiley-VCH: Weinheim, 2001; Vol. 2, pp 407.

8. (a) Forrester, A. R.; Gill, M.; Sadd, J. S.; Thomson, R. H. J. Chem. Soc., Perkin Trans. 1 1979, 612. (b) Atmaram, S.; Forrester, A. R.; Gill, M.; Thomson, R. H. J. Chem. Soc., Perkin 
Trans. 1 1981, 1721.

9. (a) Boivin, J.; Callier-Dublanchet, A.-C.; Quiclet-Sire, B.; Schiano, A.-M.; Zard, S. Z. Tetrahedron 1995, 51, 6517. (b) Zard, S. Z. Synlett 1996, 1148. (c) Boivin, J.; Schiano, A.M.; Zard, S. Z.; Zhang, H. Tetrahedron Lett. 1999, 40, 4531.

10. (a) Boivin, J.; Fouquet, E.; Zard, S. Z. Tetrahedron Lett. 1991, 32, 4299. (b) Fong, M. C.; Schiesser, C. H. Tetrahedron Lett. 1993, 34, 4347. (c) Boivin, J.; Fouquet, E.; Schiano, A.M.; Zard, S. Z. Tetrahedron 1994, 50, 1769. (d) Gagosz, F.; Zard, S. Z.; Synlett 1999, 1978.

11. (a) Lin, X.; Stien, D.; Weinreb, S. M. Org. Lett. 1999, 1, 637. (b) Lin, X.; Artman, III, G. D.; Stien, D.; Weinreb, S. M. Tetrahedron 2001, 57, 8779.

12. (a) Uchiyama, K.; Hayashi, Y.; Narasaka, K. Chem. Lett. 1998, 1261. (b) Uchiyama, K.; Hayashi, Y.; Narasaka, K. Tetrahedron 1999, 55, 8915.

13. (a) Mikami, T.; Narasaka, K. Chem. Lett. 2000, 338. (b) Mikami, T.; Narasaka, K. C. R. Acad. Sci. Paris, Ser IIc, Chim. 2001, 4, 477.

14. Kitamura, M.; Mori, Y.; Narasaka, K. Tetrahedron Lett. 2005, 46, 2373.

15. (a) Yoshida, M; Kitamura, M.; Narasaka, K. Chem. Lett. 2002, 144. (b) Yoshida, M; Kitamura, M.; Narasaka, K. Bull. Chem. Soc. Jpn. 2003, 76, 2003.

16. Koganemaru, Y.; Kitamura, M.; Narasaka, K. Chem. Lett. 2002, 784.

17. (a) Isolation; Bick, I. R. C.; Bremner, J. B.; Preston, N. W. J. Chem. Soc., Chem. Commun. 1971, 1155. (b) structure; Ros, H.-P.; Kyburz, R.; Preston, N. W.; Gallagher, R. T.; Bick, I. R. C. Helv. Chim. Acta. 1979, 62, 481.

18. (a) Klaver, W. J.; Hiemstra, H.; Speckamp, W. N. J. Am. Chem. Soc. 1989, 111, 2588. (b) Rigby, J, H.; Meyer, J. H. Synlett 1999, S1, 860. (c) Lin, X.; Stein, D.; Weinreb, S. M. Tetrahedron Lett. 2000, 41, 2333. d) Boberson, C. W.; Woerpel, K. A. J. Am. Chem. Soc. 2002, 124, 11342. (e) Washburn, D. G.; Heidebrecht, Jr. R. W.; Martin, S. F. Org. Lett. 2003, $5,3523$.

19. Tanaka, K.; Kitamura, M.; Narasaka, K. Bull. Chem. Soc. Jpn. 2005, 78, 1.

20. Tanaka, K.; Mori, Y.; Narasaka, K. Chem. Lett. 2004, 26. 